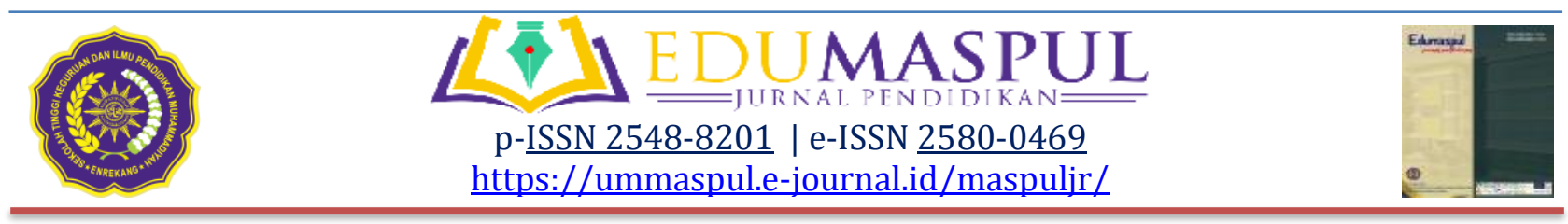

\title{
Gender Equality at the Agriculture Office in Kabupaten Enrekang
}

\author{
Suparman \\ Non Formal Education Department, STKIP Muhammadiyah Enrekang, Indonesia \\ $\bowtie$ Corresponding email: suparmanpps25@gmail.com
}

\begin{abstract}
Receive: 25-09-2019
Accepted: 04-10-2019

Published: 08-10-2019

Abstract. Gender Equality in Enrekang District (Case Study of Agricultural Service Personnel). This study aims to determine how people's perceptions of gender equality in the Agriculture Office of Enrekang District; and to find out the extent of gender equality in the Agriculture Office of Enrekang District. This type of research is a descriptive qualitative method; data collection is used by observation, in-depth interviews, documentation techniques from the results of photographs and archives owned by the local government. In this study, the target of the study was the first employee of the Agriculture Office of Enrekang District, the second community considered to be able to provide information or data in accordance with the research. The results of this study indicate that gender equality in public services, especially the Agriculture Office of Enrekang District, has not yet become a reality. This is evidenced that the number of employees with a ratio of the number of men is $89(66 \%)$ people and the number of women is $45(34 \%)$ people. The results of interviews with the community showed that support for gender equality, women's freedom to express opinions and work outside, especially working at the Agriculture Office in Enrekang District. The implication of the study were expected to provide knowledge about gender equality in the profession and provided understanding to the public about the role of women in the community.
\end{abstract}

Keywords: Gender Equality, Employees, Agriculture Office

Abstrak. Kesetaraan Gender di Kabupaten Enrekang (Studi Kasus Personil Layanan Pertanian). Penelitian ini bertujuan untuk mengetahui bagaimana persepsi masyarakat tentang kesetaraan gender di Dinas Pertanian Kabupaten Enrekang; dan untuk mengetahui sejauh mana kesetaraan gender di Dinas Pertanian Kabupaten Enrekang. Jenis penelitian ini adalah metode deskriptif kualitatif; pengumpulan data digunakan dengan observasi, wawancara mendalam, teknik dokumentasi dari hasil foto dan arsip yang dimiliki oleh pemerintah daerah. Dalam penelitian ini, sasaran penelitian adalah karyawan pertama dari Dinas Pertanian Kabupaten Enrekang, komunitas kedua yang dianggap mampu memberikan informasi atau data sesuai dengan penelitian. Hasil penelitian ini menunjukkan bahwa kesetaraan gender dalam layanan publik, terutama Dinas Pertanian Kabupaten Enrekang, belum menjadi kenyataan. Ini dibuktikan bahwa jumlah karyawan dengan rasio jumlah pria adalah 89 (66\%) orang dan jumlah wanita adalah 45 (34\%) orang. Hasil wawancara dengan masyarakat menunjukkan bahwa dukungan untuk kesetaraan gender, kebebasan perempuan untuk mengekspresikan pendapat dan bekerja di luar, terutama bekerja di Dinas Pertanian di Kabupaten Enrekang. Implikasi dari penelitian ini diharapkan dapat memberikan pengetahuan tentang kesetaraan gender dalam profesi dan memberikan pemahaman kepada publik tentang peran perempuan dalam masyarakat.

Kata kunci: Kesetaraan Gender, Pegawai, Dinas Pertanian 


\section{INTRODUCTION}

The provision of equal opportunities for women to carry out activities in various fields as men does not guarantee the realization of gender justice. The main cause is the low quality of women's resources resulting in their inability to compete with men in development so that an important position in government and the business world is dominated by men. Gender differences do not really matter as long as they do not create gender injustice. This problem will arise when gender differences create various injustices, especially for women. To understand how gender equality caused of gender inequality needs to be manifestations of injustice in various forms, such as marginalization, subordination, stereotyping, violence and workload (Fakih, 1997: 12-23).

Justice to people's lives should be enjoyed by all elements of society without recognizing their status, position, race, and gender, so that a just and prosperous social life is created, but the social reality that occurs today, it turns out that there are still many injustices which occur to various fields of social life such as education, development, and employment. Until now in Kabupaten Enrekang in particular, the inequality of rights between men and women so that it needs to be made in a statement that the state, as well as the community, respects the equal rights of human rights so that there is gender justice between men and women in the field education, work, and development because we already know that every place of work in Enrekang is dominated by men. One place of work that is still dominated by men in the Department of Agriculture, based on the results of preliminary observations obtained that the number of men is 89 people and women is 45 people including all civil servants.

Every citizen of Kabupaten Enrekang basically has the right to obtain gender justice. Therefore, they should have the same access in all matters, including education, development, decision making, health, and other important services. Education is a human right. However, there are still many parties who tihink the obtaining an education is a human right, especially for women. Eventhough education is the road to liberation from poverty.

\section{METHODS}

Type of research used is descriptive qualitative research, in which this study seeks to answer questions about gender equality. The focus is gender equality in the Enrekang Agricultural Service. To find out researcher took information on several respondents taken as sample of a purposive sampling technique. Respondents referred to: 1) the community of 7 people includes 2 religious leaders, 2 indicators, and 3 clouds/ public people; 2) Enrekang Agricultural Service staffs 10 people including 4 indicators, 3 men and 3 women. Because of the presence of respondents and the number of respondents determined it will be easier to get information about this research.

The main instrument in this research is the researcher himself. As the main instrument, the researchers starting from the initial stages of research to the result of this study were all carried out by researchers. In addition, to support the achievement of the result of the study, the researchers used tools such as interview guides, documentation and field notes. The 
instruments used are notes, observation sheets while the interview instruments are notebooks, hand phones, camera, and interview guidelines.

\section{RESULTS AND DISCUSSION}

In the life of the community, both men and women need gender equality and the freedom between them in terms of work such as women wants to work outside the home. After I looked directly at the Department of Agriculture the respondent's statement that there are men who are the head of the field which is dominated by men starting from being the Head of Service, Secretary, Head of Subdivision, General Personnel, Head of Subdivision of Finance, Head of Food Crops Division, Head of Plantation, Head of Forestry, Head of Animal Husbandry Division, the Head of UPTD for each sub district, the men still dominated.

There were several important things to know about gender equality in the Agricultural Service, i.e.:

\section{a. The Role of Men and Women}

The role of men and women can take same role even though in the Agricultural Service there are still men that dominated because the number of men more than the women. The men are 89 people and the women are 45 people. Based on the results of interviews for $S M$, I see that women working in the Agriculture Service can be equal to men because many women whose education are equal to men and women are diligent in their work. So in the future, there needs to be a consideration so that women can get a role work in accordance with their expectation. b. Division of Work Between Men and Women

The division of labor in the Agriculture Service between men and women is adjusted to their abilities and place and has their respective functions both men and women so that women are not excluded or discrimination against women occurs. In accordance with the result of the interview presented by $B R$, "The division of labor in the Department of Agriculture is positioning women in certain jobs with an equal level of work. Whereas the Agricultural Service is mostly technicians, consequently, most of the work is outside the office or in the field so more physical and mental needs are needed. Hence, it takes a lot of male employees compared to women. For example, in the forestry sector, patrols are often carried out in forest areas, which enable them to meet other bloggers" (Result of an interview, 14 January 2019).

Conclusion can be drawn from the respondent's statement that positioning women in their place and in accordance with their fields is appropriate but from every field, there are still men that dominate. Gender equality can be seen from four indicators, namely access, control, participation, and benefits, i.e.:

\section{1) Access Factors}

Based on the result of interviews for staffs of Department of Agriculture and observations respondents said that they had the same access to get opportunities to get positions, as stated by $S T$. Based on the respondent's statement, it can be concluded that with access factors such as obtaining a position there is no obstacle to anyone as long as he 
able and before holding the position there is already a decree or decree for each holders so to obtain a position in a place of employment is not easy.

\section{2) Factors of Participation}

In terms of participation in the implementation of activities and the assignment to tasks is a still dominated by men even though the level education of women is higher than the men. Expressed by MT. Based on the results of interviews for respondents, it can be concluded that the factor of male participation is more dominant as in the case of activities in the field because it involves physical and mental.

\section{3) Benefit Factors}

The benefits obtained by the Department of Agriculture employees can be seen from the policies implemented by each employee. From the interview result, it can be concluded that every position obtained by each employee in the Agriculture Service must be utilized properly and carry out the mandate as well as possible without anyone being harmed.

\section{c. Control Factors}

Control factors must be given equally to men and women. At the office of Agriculture as stated by the respondent named $M A$. Based on the respondent's statement, it can be concluded that with the Office of Agriculture there are also sanctions and awards applied so that every employee must be disciplined in accordance with the existing rules. Hopefully, that there is no mutual jealousy among these employees.
Efforts to fight for gender equality in the Agriculture Service are needed with the ongoing efforts to improve education for women. Because the increase of level education for women, it will improve the competency and competitiveness of women in the field of employment as revealed by employees, namely $M T$. It can be concluded that in order to improve all education in the Department of Agriculture staff, it is necessary to have various sources that can support the improvement education. Basically, everyone agrees that women and men are different. However, gender is not male and female sex as God's gift. Gender emphasizes the different roles and functions that exist and is made by the community.

In reality of life, there have been differences in the social roles of men and women who gave rise to differences in social status in society, men were more favored than women through social construction. Gender differences between men and women are determined by a number of factors that form, which are then socialized, strengthened, even shaped through social of cultural, and perpetuated by the interpretation of religion and myths.

Gender differences are often used by the community to form the division of roles (work) of men and women on the basis of these differences. As result, there was a division of gender roles, namely domestic roles, and public roles. Domestic roles tend not to generate money, power, and influence. This role is more left to women, while the public role that generates money, power and influence is left to men. 
The result of an imbalanced division of labor gives birth to inequality in the roles of men and women which results in gender injustice which harms women. In Indonesia, gender inequality is seen in all aspects, including in the family, population, education, economy, employment, and government. This unequal difference between the roles of men and women is also strongly influenced by the culture of Indonesia society which consists of many ethnic and ethnic groups. Every tribal community in Indonesia has its own characteristics in interpreting gender roles in Indonesia.

In Indonesia, the issue of gender equality has recently become and endless issue and is still being fought at both the executive and legislative levels. The issue of gender equality includes the substantives understanding of the gender perspective policy itself. Increasing awareness and understanding must be accompanied by the representation of women in state institutions, especially policy making institutions. Considering that women still experience inequality in the fields of education, social, political, and economic only because the development of Indonesian people's knowledge about gender itself is still very slow. Even though women are placed in domestic roles in the family, the position of Indonesian women family environment is always echoed. Because it acts as a breadwinner, the position of the head use it acts as a breadwinner, the position of the head of the household, in general, will be handed over to the man/ husband, except if the woman is a widow or no male in a family.

Based on the results of the interview it can be concluded that in general almost all those who worked with certain positions is due to inequality in them. The conclusion that can be drawn from the respondent's answer is that women's work is always related to light work because it is seen that every job of Enrekang such as office is still dominated by men as the leaders.

\section{c. A View of Women's Stereotypes}

A view of women's subordination before, which also cause emerged stereotypes. Stereotypes are a form standardizing a view of a human group by giving certain characteristics, regardless of individual abilities. Until now the understanding of women as stereotypes was still quite large. It is recognized that there is still a tendency towards perception confirming that in the case of inheritance distribution, women have the right to obtain half a portion of men (point 3).

As is the case of political activities, religious leaders still assume that women are inferior to men. Woman as human beings, like men, women will learn about life based on their experience. However, the biological differences between men and women cause different experiences. Women must feel menstruation, pregnancy, childbirth, breastfeeding which is experiencing that will never happen to men in general. That is what further encourages women to try to preserve life by learning from their own experiences in their people. In common sense, it is appropriate if women are free to determine what will be done in carrying out this life management task. However, in 
reality of life, women no longer have the right to regulate life. All aspects of life are determined by a force outside the lives of women, that power is politics. Politics that puts women under men or husbands.

\section{CONCLUSION}

Based on the results of research obtained in the field for approximately one month, as well as information from respondents on gender equality in the Agriculture Office of in Kabupaten Enrekang. The following are some conclusions based on the results of the analysis of data, as follows: (1) Gender equality is a common condition of men and women to get opportunities and rights as human beings and to be able to play a role and participate in politics, work, and education in the community. With the existence of gender equality, women can gain the freedom to study; women can compete, improve their lives, and have the same degree as men; (2) Gender equality in Department of Agriculture has not yet occurred because the division of positions to become head of the field is still male which dominates. The division of labor between men and women in the Department of Agriculture is done by men and women but more technicians dominated by men because they need physical and mental.

\section{References}

[1] Asyhari. (2009). Gender Equality According to Nasaruddin Umar and Ratna Megawangi (Case Study of Thinking Two Figures). Yogyakarta: Journal.

[2] Fakih, Mansour. (2013). Gender Analysis \& Social Transformation. Yogyakarta: Learning Library.

[3] Juliani, Rany. (2011). Workers' Perception of Gender Equality and Justice in the Implementation of Work Regulations at PT.
ITS. Purwakarta Regency, West Java Province. Bogor: Journal.

[4] Narwoko, J. Dwi \& Bagong Suyanto. (2010). Sociology of Introduction and Applied Texts (Third Edition). Jakarta: Kencana Prenada Media Group.

[5] Saifuddin, Achmad Fedyani. (2010). Introduction to Social Theories (From the Theory of Functionalism to PostModernism). Jakarta: Indonesian Torch Library Foundation.

[6] Sugiyono. (2015). Educational Research Methods (Quantitative, Approaches Qualitative and $R \& D$ ). Bandung: Alfabeta.

\section{Author profile}

Suparman, was born on February 20, 1990 in Bo'di, the first child of four siblings who were the son of Muhajir and Tawia. In 1997, the author began entering elementary school education at 83 Dante Mararih Enrekang State Elementary School and finished in 2003. Then in the same year (2003) the writer continued his education to junior high school at SMPN 4 Baraka Enrekang and finished in in 2006. In 2006, the author continued his education to the high school in SMA Negeri 1 Baraka Enrekang and finished in 2009. Then in 2009 the writer continued his education through the path New Student Admission Selection (SPMB) and accepted at the Department of Sociology Education, Faculty of Teacher Training and Education, University of Muhammadiyah Makassar, Undergraduate Study Program (S1). In 2013, the author completed a study by working on a scientific work entitled "Improving Learning Outcomes of Sociology Subject of Social Interaction (Dating Institution) Through Cooperative Learning Models of Student Teams Achievement Division Types in Class XB Students of SMA Negeri 1 Baraka, Enrekang Regency. Then in 2014 the writer took the master program at the Makassar State University taking the social science program specific to sociology education and in 2016 the author completed his study by working on a scientific work entitled "The Dual Role of the Farmer's Wife (Case Study in the Warian Village of the Sub-District Baraka Enrekang Regency)". 